\title{
THE NATURAL LAW FOUNDATIONS OF LORD DENNING'S THOUGHT AND WORK
}

\author{
Andrew Phang*
}

\section{INTRODUCTION}

There is a constant tension in the law between certainty on the one hand and fairness on the other. While it is true that both are not necessarily incompatible with each other, there are numerous occasions when conflicts do occur. Not surprisingly, therefore, the focus in English and (probably) Commonwealth law is on the former. This explains, in large part, the rule-oriented and positivistic nature of law in these various legal systems. ${ }^{1}$ The primary concern in this regard is with the maintenance of the objective and, consequently, of stability, eschewing any descent into the vagueness and subjectivity that a contrary approach might entail. There is, in other words, no necessary connection as such between the law on the one hand and morality on the other. While there is much merit in this approach inasmuch as it avoids unnecessary uncertainty once the applicable legal rule(s) have been identified, it loses force if it can be demonstrated that the law is premised on an objective set of higher-order morality.

Lord Denning's thought and work (as encompassed within both his legal judgments as well as extra-judicial writings and lectures) in fact evince an approach that is based on the assumption that there are in fact objective

\footnotetext{
*Associate Professor, Faculty of Law, National University of Singapore. This is a highly abbreviated version of a lengthier paper. The full version may be obtained from the author (c/o The Faculty of Law, National University of Singapore, 39 Law Link, Singapore 117589; e-mail: lawapbl@nus.edu.sg).

I am grateful to Ms.Rosemary Dunhill, County Archivist, Hampshire Record Office, and her staff for all their help in retrieving materials from the Denning archive; to Ms.Sheena McMurtrie, Editor of the Denning Law Journal, for all her kindness and assistance; as well as to Mr.Aqbal Singh for his comments and encouragement. All errors, however, remain mine alone.

${ }^{1}$ See eg P.S.Atiyah and R.S.Summers, Form and Substance in Anglo-American Law (Clarendon Press, 1987); P.Devlin, The Enforcement of Morals (Oxford University Press, 1965) at Ch.III, esp. at pp.44 and 51; and A.Phang, "Positivism in the English Law of Contract" (1992) 55 M.L.R. 102.
} 
and universal values. His is a natural law approach, which is premised in no uncertain terms upon a religious foundation - or, to be more precise, on a Christian foundation. For him, religion and law are inextricably connected together in a symbiotic relationship. There is, to Lord Denning, a higher (and objective) law, against which all legal rules and principles have to be measured. The objection from subjectivity and relativity does not therefore bother him. And this approach is evident throughout his thought and work. In the sphere of binding precedent or stare decisis, for example, Lord Denning always championed fairness at the expense of certainty, although the very doctrine itself was concerned more with the latter than the former. ${ }^{2}$ And such an approach also characterised his activist approach towards the interpretation of statutes. ${ }^{3}$ In the sphere of substantive law, he was a constant advocate of fairness, even if this meant that the existing legal rules had to be either circumvented or even abrogated altogether. All this was, of course, anathema to the general approach embodied in the Commonwealth in general and England in particular. ${ }^{4}$ Indeed, Lord Denning has been criticised (on occasion even trenchantly) precisely because of his alleged iconoclasm. ${ }^{5}$ One oft-cited criticism has been that his approach has engendered excessive uncertainty in the law - an uncertainty that has undermined the adjudicative process as well as the attainment of justice. The present essay argues otherwise; its purpose is threefold. I will first outline Lord Denning's ethical and religious beliefs. I will then briefly explore how his ethical and religious beliefs are manifested (in the process of application, in particular) in the law. Finally, I will attempt to assess not only the influences on but also (and more importantly) the possible justifications for Denning's beliefs.

\footnotetext{
${ }^{2}$ For an extended discussion by Lord Denning himself, see Lord Denning, The Discipline of Law (Butterworths, 1979) at Pt.7. However, it is important to note that Denning was not against the doctrine of precedent because he championed subjective judicial fiat. On the contrary, he is at pains to point out that the doctrine is still very important: see at p.314.

${ }^{3}$ See generally Denning, supran.2 at pp.9-22. See also Lord Denning, The Closing Chapter (Butterworths, 1983) at p.97 et seq, and where, inter alia, there is also Biblical reference to adherence to the spirit, rather than the letter, of the law.

${ }^{4}$ The position in the United States of America is far more substantive: see e.g., Atiyah \& Summers, supra n.1.

5 And see Lord Denning himself: "The Way of An Iconoclast" (1959-1960) 5 J.S.P.T.L. (N.S.) 77 (this address by Lord Denning was also published in (1960) 3 Sydney Law Rev. 209).
} 


\section{LORD DENNING'S ETHICAL AND RELIGIOUS BELIEFS}

\section{In General}

As already mentioned, the stock criticism of Lord Denning's thought and work has centred on their perceived arbitrariness and the alleged uncertainty that results. ${ }^{6}$

As I shall attempt to demonstrate, these 'popular' perceptions of Denning's thought and work could not be further from the truth. Denning, as already mentioned, perceived his thought and work to be based on the objective truth to be located in the religious foundations of Christianity. ${ }^{7}$ It is, however, perhaps ironic to note that Denning himself always claimed to be wary of theory and endorsed experience and practice instead. $^{8}$

Turning to Denning's specific enunciations of his beliefs, in a brief typescript entitled "What Life Has Taught Me," Lord Denning commences by stating that " $[t]$ he most important thing that life has taught me is to believe in God." He then proceeds to state that this belief is due both to his upbringing as well as to his experience "in going through life." $" 10$

Insofar as the experiential aspect is concerned, he says that "[m]y experience as a lawyer and as a judge has verified what I was taught about God." To him, law and religion are inextricably connected: "The aim of

\footnotetext{
${ }^{6}$ The literature on this point is voluminous; and see generally the following excellent collections of essays: P.Robson \& P.Watchman (eds.), Justice, Lord Denning and the Constitution (Gower, 1981) and J.L.Jowell \& P.W.B.McAuslan (eds.), Lord Denning: The Judge and the Law (Sweet \& Maxwell, 1984). The former collection is far more critical although the latter does not pull its punches either. See also Lord Wilberforce, "The Academics and Lord Denning" (1985) 5 O.J.L.S. 439 at p.439.

${ }^{7}$ See also Lord Edmund-Davies, "Lord Denning: Christian Advocate and Judge" [1986] Denning L.J. 41 at pp.41 and 47.

${ }^{8}$ See $e . g$., Lord Justice Denning, "The Independence of the Judges" in B.W.Harvey (ed.), The Lawyer and Justice - A collection of addresses by judges and jurists to the Holdsworth Club of The University of Birmingham (Sweet \& Maxwell, 1978), pp.55-69 at pp.56 and 62; and, by the same author, The Changing Law (Stevens \& Sons Limited, 1953) at pp.15-16 as well as The Family Story (Butterworths, 1981) at p.240. Though $c f$. his article, "The Universities and Law Reform" (1947-1951) 1 J.S.P.T.L. (N.S.) 258 at pp.268-269.

${ }^{9}$ On file at the Hampshire Record Office.

${ }^{10}$ See also A.T.Denning, "Why I Believe In God" (Transcript of a talk delivered on the B.B.C. Home Service, Tuesday, 14th September, 1943 at 10.15 p.m.) (on file at the Hampshire Record Office). All references hereafter will be to page numbers of the transcript itself. See also Lord Edmund-Davies, supra $\mathrm{n} .7$ at p.41, where the learned Law Lord refers to Denning's service as a Churchwarden as well as member of the Parishional Church Council. Denning was of course also for many years President of the Lawyers' Christian Fellowship. See, further, Denning, The Family Story, supra n 8 at pp.vi and 180-183.
} 


\section{DENNING LAW JOURNAL}

the law is to see that truth is observed and that justice is done between man and man."11 On another occasion, Lord Denning observed that "without religion there can be no morality and without morality there can be no law."

As to the question as to what constitute "truth" and "justice," Lord Denning is of the view that they are "eternal" and that they are the product of a person's spirit. ${ }^{13}$ And as to how the "right spirit" is created in man, Lord Denning is of the view that "[t]hat is the province of religion" - in particular, the Christian religion. He elaborates thus:

\section{"Religion concerns the spirit in man whereby he is able to recognise what is truth and what is justice: whereas law is only the application, however imperfectly, of truth and justice in our everyday affairs." 14}

Indeed, "the spirit in Man, when it reaches the highest and wisest plane, is but the reflection of the spirit of God." And in an amazingly candid passage, Lord Denning states thus:

"I do know that in the great experiences of life, and indeed in the small ones too, such strength as I have is of God, and the weakness is mine. Need I enumerate the experiences? Take the hard things. When faced with a task on which great issues depend; when high hopes lie shattered; when anxiety gnaws deep; or when overwhelmed by grief; where can I turn for help but to God? Or take the joyful things: A hard task attempted or done; the happiness of family life; or the beauty of nature; where can I turn for thankfulness but to God? All experiences convince me, not only that God is everpresent, but also that it is by contact with the spirit of God

\footnotetext{
"See Denning, "Why I Believe In God," supra n.10 at p.2. See also Denning, infra n.20 at p.8.

${ }^{12}$ See Lord Denning, “The Right Standards of Conduct" (1957) Law Society's Gazette 609 at p.609. This conviction is indeed often repeated in his extra-judicial writings.

${ }^{13}$ See Denning, supra.n.9 (emphasis added). See also Denning, "Why I Believe in God" supra n.10 at p.2.

${ }^{14}$ See Denning, supra n.9 (emphasis added). See also Denning, "Why I Believe In God" supra.n.10 at p.3. See, further, by the same author, "Address Delivered by the Rt. Hon. The Lord Denning, Master of the Rolls, at the Annual Service on October 6th" (Lawyers' Christian Fellowship, 1977; on file at the Hampshire Record Office; hereafter referred to as "Address 1977").
} 


\section{NATURAL LAW FOUNDATIONS}

that the spirit in Man reaches its highest and wisest plane."15

It is suggested that the "spirit of God" Denning refers to is probably a reference to the Holy Spirit, who is also described in the Bible, inter alia, as a "counsellor." 16

In an address to the Medico-Legal Society, Lord Denning elaborated on the concept of "justice"17 by stating that it "is what the right-thinking members of the community believe to be fair." 18

The upshot of all this is that:

" $[\mathrm{L}]$ awyers should be men of religion: and speaking generally that has always been the case in this country. It is the reason why the common law of England is so great. The law has been moulded for centuries by Judges who have been brought up in the Christian faith. The precepts of religion, consciously or unconsciously, have been their guide in the administration of justice."19

In a message given to the Quarterly Meeting of the Lawyers' Christian Fellowship held at the Law Society on 22 May 1950, entitled "The Influence of Religion on Law, ${ }^{, 20}$ Denning L.J. (as he then was) observed that "[i]n the days when the Bible was first put into English the Judges laid down rules which were undoubtedly influenced by Bible teaching."21 More importantly, perhaps, he points out (in the same message) to "the more fundamental teaching of our Lord:"22 "the Gospel of Love,"23 i.e., that one is to love God first and then our neighbour as ourselves. ${ }^{24}$ Although " $[t]$ his is a precept of religion, not of morals nor of law,"25

\footnotetext{
${ }^{15}$ See Denning, supra n.9 (part of this passage is handwritten). See also Denning, "Why I Believe in God" supra n.10 at p.4.

${ }^{16}$ See John 14: 16, 26; 15:26 and 16:7. See also Denning, "Address 1977" supra n.14.

${ }^{17}$ Interestingly, in his coat of arms, Denning took as his motto, "Fiat justitia" viz., "Let justice be done:" although he later found the actual origin of this motto to be rather dubious: see Denning, The Family Story, supra n.8 at p.172.

${ }^{18}$ See Lord Denning, "The Freedom of the Individual To-day" (1977) 45 Medico-Legal J. 49 at p.55 (emphasis added).

${ }^{19}$ See Denning, "Why I Believe in God" supra n.10 at p.3. See also, by the same author, "The Influence of Religion" in The Changing Law, supra n.8 at p.109 (hereafter "Influence").

${ }^{20}$ In pamphlet form (Bletchley Printers Ltd., 1950) (hereafter "The Influence of Religion on Law"). See also, by the same author, "Influence" supra n.19.

${ }^{21}$ See Denning, "The Infuence of Religion on Law" supra n.20 at p.2.

${ }^{22}$ Ibid at p.3.

23 Ibid.

${ }^{24}$ Citing from Luke 10: 25-28: see ibid. See also infra n.81.

${ }^{25}$ Ibid.
} 
Denning was of the view, nevertheless, that "it is not unrelated to them,",26 for "[i]n social organisation, love finds its primary expression through justice": ${ }^{27}$ "The two - love and justice - are interdependent."

Insofar as societal welfare is concerned, in a lecture delivered as far back as $1953,{ }^{29}$ Denning argued that "the Welfare State has come into being by a true application of Christian principles, but ... there is a danger of its being mishandled and abused by people who have no knowledge of those principles and seek only their own advantage. ${ }^{.30}$ Denning argues that the recapture of love and service through Christian principles is essential to combat such abuse.

\section{In The Law}

\section{(i) General:}

What precisely did Lord Denning stand for in the more explicitly legal realm? He was, in fact, a passionate advocate of many institutions that are traditional elements underlying the Rule of Law: for instance, the independence of the judiciary ${ }^{31}$ and various freedoms (including freedom of the press ${ }^{32}$ ). One overarching theme centres, in fact, on the need to restrain the misuse of power. ${ }^{33} \mathrm{He}$ also advocated equality for women, ${ }^{34}$ although here writers have argued that Denning's judgments (particularly in the sphere of family law) have fallen short of the mark. ${ }^{35}$

\footnotetext{
${ }^{26}$ Ibid.

${ }^{27}$ Ibid.

${ }^{28}$ Ibid.
}

${ }^{29}$ See Sir Alfred Denning, The Christian Approach to the Welfare State (The 17th Shaftesbury Lecture, The Chaseton Press of H.Williams \& Son, Ltd., 1953).

${ }^{30} \mathrm{Ibid}$ at p.3.

${ }^{31}$ See e.g., Denning, "The Independence of the Judges" supra n. 8 and, by the same author, "The Independence and Impartiality of the Judges" (1954) 71 S.A.L.J. 345.

${ }^{32}$ See e.g., Sir Alfred Denning, The Road to Justice (Stevens \& Sons Limited, 1955) at Ch.4 and, by the same author, "Law and Life in Our Time" (1967) 41 Australian L.J. 224 at p.227 - although the learned judge correctly points to the need for balance, so that the freedom not be abused.

${ }^{33}$ And see generally Denning, "Restraining the Misuse of Power" in Jubilee Lectures Celebrating the Foundation of the Faculty of Law, University of Birmingham (Wildy \& Sons Ltd., 1981) and, by the same author, "Misuse of Power" (1981) 55 Australian L.J. 720.

Reference may also be made to Lord Denning's more recent works: see e.g., The Due Process of Law (Butterworths, 1980) and What Next In The Law (Butterworths, 1982) especially at Pt.8.

${ }^{34}$ See e.g., "The Rights of Women" in Denning, The Changing Law, supra n. 8 at pp.79-98 and, by the same author, The Equality of Women (Eleanor Rathbone Memorial Lecture, Liverpool University Press, 1960).

${ }^{35}$ See e.g., M.D.A.Freeman, "Family Matters" in Ch.4 of Jowell \& McAuslan, supra n.6. 
It should also be noted that although often perceived as radical, Denning did not in fact advocate rampant activism. Referring, for example, to the reform of family law in 1977, he was of the view any reform would be too complex and widespread for judge to handle, although he opined that "judge can work on a minor scale within the existing law.","36

In a later work, Denning vigorously denied the charge of being politically motivated; he emphatically stated:

"I deny the charge. Some decisions are fraught with political consequences - such as decisions about trade unions or local authorities or ministers. Whichever way the case goes, one side or the other will say it is a 'political' decision. That is their way of saying that it is a policy decision with which they disagree., 37

(ii) The Law of Contract:

This area is the primary illustrative focus, although I hasten to add that constraints of space allow only a few areas of contract law to be considered. ${ }^{38}$

A more general observation by Lord Denning himself may be apposite before turning to the more specific areas of contract law proper. Denning observes that insofar as the law of contract was concerned:

"[T]he influence of the Church was immense: because the Church courts assumed jurisdiction in matters of conscience. Originally in English law a promise was not enforceable unless is [sic.] was hedged about with the formality of a seal. But the teaching of the Church was in favour of rejecting formalities and insisting on good faith. The just man is 'he that sweareth not his neighbour and disappointeth him not, though it were to his own hindrance. ${ }^{, 39}$ If a man made a promise and did not keep it,

\footnotetext{
${ }^{36}$ See "Denning and Scarman: A conversation between Lord Denning, Master of the Rolls, and Lord Justice Scarman" (B.B.C. Broadcasting Corporation Transcript, Radio Three, Talks and Documentaries Department, recorded Wednesday 19th January, 1977, Transmission: Thursday 3rd March,1977, on file at the Hampshire Record Office) at p.9; Denning, significantly in my view, then proceeds to talk about consumer protection as well.

${ }^{37}$ See Denning, What Next In The Law, supra n.33 at p.333 (emphasis added). See also, by the same author, The Family Story, supra n.8 at p.28.

${ }^{38}$ The reader is directed to Professor Atiyah's very perceptive overview published shortly after Lord Denning's retirement: see P.S.Atiyah, "Contract and Tort" in Ch.2 of Jowell \& McAuslan, supra n.6.

${ }^{39}$ Citing from Psalm 15.4.
} 


\section{DENNING LAW JOURNAL}

the ecclesiastical courts would punish him for breach of faith." ${ }^{40}$

Unfortunately, however, contract law today has been secularized, with the emphasis on rationalism and individualism, ${ }^{41}$ and this may well explain why courts have been unable to mediate objectively the tension (mentioned at the outset of this article) between certainty and technicality on the one hand and fairness on the other. As Professor Berman pertinently argues, a return to the objective religious foundations will enable a new (and more coherent) theory of contract law to be developed. ${ }^{42}$ Denning would surely agree with this suggestion.

Turning to the more specific areas of contract law proper, the doctrine of consideration is familiar to all law students. Yet, it is not without problems. ${ }^{43}$ Indeed, a strict application of it often leads to injustice. ${ }^{44}$ This is particularly so, perhaps, in the situation concerning the promise to take part payment in full discharge of a debt already owed; this has, in accordance with the leading authorities (notably that of the House of Lords in Foakes v. Beer ${ }^{45}$ ), been traditionally held not to constitute consideration. This being the case, the various exceptions that mitigate possible injustice become of signal importance. In this regard, the most significant exception is the doctrine of promissory estoppel, which has its origins in the seminal judgment of Denning J. (as he then was) in Central London Property Trust Ltd. v. High Trees House Ltd ${ }^{46}$ Briefly put, if one person makes to another an unambiguous representation that he or she will not enforce his or her strict legal rights, intending that other party to act on it, and that party does act on it, then the representor/promisor will not be allowed to resile from his or her promise if it would be inequitable to do so. ${ }^{47}$

${ }^{40}$ See Denning, supra n. 20 at p.7. See also, by the same author, "Influence" supra n.19 at pp.104-105.

${ }^{41}$ See generally Harold J.Berman, "The Religious Sources of General Contract Law: An Historical Perspective" (1986) Journal of Law and Religion 4 (reprinted in Ch.7 of Harold J.Berman, Faith and Order: The Reconciliation of Law and Religion (Scholars Press, 1993)).

${ }^{42}$ See Berman, supra n. 41 .

43 And see the calls for abolition by the English Law Revision Committee in 1937

(Cmd.5449). See also A.Phang, "Consideration at the Crossroads" (1991) 107 L.Q.R. 21.

${ }^{44}$ The recent development in Williams v. Roffey Bros. \& Nicholls (Contractors) Ltd. [1991] 1

Q.B. 1 has not, however, significantly mitigated such injustice; see, in particular, $R e$

Selectmove [1995] I W.L.R. 474. See also A.Phang, "Acceptance by Silence and

Consideration Reined In" [1994] L.M.C.L.Q. 336.

${ }^{45}$ (1884) 9 App.Cas. 605, reaffirming the so-called rule in Pinnel's Case (1602) 5 Co.Rep.

$117 \mathrm{a}$.

${ }^{46}$ [1947] K.B. 180.

${ }^{47}$ This is, of course, a very rough description: much more elaboration is required. 


\section{NATURAL LAW FOUNDATIONS}

The High Trees case is commonly hailed as a landmark in the common law of contract. ${ }^{48}$ However, it was also a radical step forward. To Denning himself, the High Trees case "helped to narrow [the] gap" between the "strict rules and the social necessities of the 20th century," thus achieving justice in the process.

Leaving aside certain problematic aspects of the doctrine, ${ }^{50}$ when all is said and done, however, Denning reminds us once again that the doctrine of promissory estoppel is based on moral foundations; it is a doctrine that aids in the attainment of justice and the avoidance of the technicality and injustice that have been encrusted around the doctrine of consideration. Indeed, of the doctrine of consideration, Denning says that "[i]t has been replaced by the better precept: 'My word is my bond,' irrespective of whether there is consideration to support it." perhaps, there are resonances of Christian principles when he proceeds to add thus:

"Once a man gives a promise or assurance to his neighbour - on which his neighbour relies - he should not be allowed to go back on it. In stating the principle, and its extensions, the lawyers use the archaic word 'estoppel'. I would prefer to put it in language which the ordinary man understands: It is a principle of justice and of equity."

Lord Denning was also very activist in the sphere of implied terms, which he viewed as centring on the demands of what he termed "simple justice;",53 and he made no secret that in implying terms, courts were, in

${ }^{48}$ [1947] K.B. 180. See also Denning, supra n.2 at pp.197-223 (an extended account by Lord Denning himself).

${ }^{49}$ See Denning, ibid at p.197.

${ }^{50}$ E.g., the concept of detriment (which Denning eschewed: see e.g., W.J. Alan \& Co v. El Nasr Export and Import Co. [1972] 2 Q.B. 189 at p.213; but $c f$. Atiyah, supra n.38 at p.35 and A.B.L.Phang, Cheshire, Fifoot and Furmston's Law of Contract - Second Singapore and Malaysian Edition (Butterworths Asia, 1998) at pp.202-205) and whether or not the doctrine could be used as a sword as well (which Denning also eschewed: see Combe v. Combe [1951] 2 K.B. 215; though $c f$., in a separate videotaped interview: M.Dockray, E.Lomnicka, S.Lee \& J.Fortin, Review of The Denning Interviews (Video Cassettes of Interviews with Lord Denning of Whitchurch) (1985) 101 L.Q.R. 137 at p.140 and the leading Australian High Court decision of Walton Stores (Interstate) Ltd. v. Maher (1988) 164 C.L.R. 387).

${ }^{51}$ See Denning, supra $\mathrm{n} .2$ at p.223.

${ }^{52}$ Ibid (emphasis added).

${ }^{53}$ See Denning, supra n.2 at p.33. See also ibid at p.34 (reference to "reason and justice"). 


\section{DENNING LAW JOURNAL}

effect, "[filling] in the gaps." City Council v. Irwin, that the courts could imply terms whenever it was "reasonable" into the contract is not in the least surprising. ${ }^{55}$ Although this general principle was rejected by the House of Lords, ${ }^{56}$ Denning actually won a victory of sorts, for in the Liverpool City Council case itself, the House drew a distinction between "terms implied in fact" and "terms implied in law," the test of reasonableness and public policy applying to the latter, which constituted a broader category of terms implied in a particular class of contracts, even if this would be contrary to the actual or presumed intentions of the parties concerned. What was particularly interesting was the ambiguity of the language utilised, ${ }^{58}$ which suggests that the House was not very comfortable with the distinction, in particular, the criterion of reasonableness. Denning was nevertheless quick to seize upon this distinction and (naturally) gave it his full endorsement. ${ }^{59}$ This was not a "full victory" as such, but it represented some headway, so to speak. What is particularly interesting about this distinction in general and the category of "terms implied in law" in particular is the focus on the concept of "reasonableness" that, in turn, correlates to Denning's idea of what is "justice." And "justice" is, as we have seen, ultimately linked to Denning's own Christian values. ${ }^{61}$

Lord Denning is perhaps best known for his judgments geared towards aiding (in particular) consumers with respect to exception clauses. This was not, however, always the case. Denning, in fact, lamented his involvement in the decision of L'Estrange v. Graucob, which held that a contracting party is, in the absence of fraud or misrepresentation, ${ }^{62}$ bound by exception clauses in a contract on appending his or her signature to it. ${ }^{63}$

But things rapidly (and radically) changed by the time Denning was appointed to the bench. The famous doctrine of fundamental breach as a

\footnotetext{
${ }^{54}$ Ibid at p.34.

55 [1976] Q.B. 319.

${ }^{56}$ See [1977] A.C. 239. See also Atiyah, supra n.38 at pp.37-39.

${ }^{57}$ Not explicitly: but the point has been since reaffirmed in a number of cases: see Scally v. Southern Health and Social Services Board [1992] 1 A.C. 294; Spring v. Guardian Assurance plc [1993] 2 All E.R. 273 at 296; and Malik v. Bank of Credit and Commerce Intemational S.A. [1997] 3 W.L.R. 95 at 108-109.

${ }^{58}$ See generally A.B.L.Phang, "Implied Terms Revisited" [1990] J.B.L. 394 and, by the same author, "Implied Terms in English Law - Some Recent Developments" [1993] J.B.L. 242.

${ }^{59}$ See Shell U.K. Ltd. v. Lostock Garage Ltd. [1976] 1 W.L.R. 1187 at 1196-1197.

${ }^{60}$ See supra n.18.

${ }^{61}$ See e.g., supra n.19.

${ }^{62}$ See [1934] 2 K.B. 394. And on the last-mentioned point, see Curtis v. Chemical Cleaning and Dyeing Co. [1951] 1 K.B. 805.

${ }^{63}$ See $e . g$., Denning, supra n. 12 at p.610 and, by the same author, The Family Story, supra $\mathrm{n} .8$ at pp.99 and 174-175.
} 
rule of law finds its genesis with Denning himself. ${ }^{64}$ It may, in fact, be said that the underlying impetus for Denning's approach towards exception clauses stemmed from the perception of the need to prevent abuse which (in turn) is embodied in Christian doctrine. ${ }^{65}$ However, this doctrine was finally (and decisively) rejected by the House of Lords in Photo Production Ltd. v. Securicor Transport Ltd. ${ }^{66}$

Notwithstanding the sounding of the death knell for fundamental breach as a rule of law in the Photo Production case, ${ }^{67}$ Denning could take more than scant consolation in the enactment (in 1977) of the Unfair Contract Terms Act. ${ }^{68}$

On an even broader level is Lord Denning's controversial statement of principle with respect to inequality of bargaining power that he enunciated in Lloyd's Bank Ltd. v. Bundy. ${ }^{69}$ Denning's statement of principle has often been read as embodying too general and vague a standard that only emphasises inequality of bargaining power and does away with the necessity for some form of wrongdoing on the part of defendant. It has therefore been rejected by the courts in no uncertain terms. ${ }^{70}$ However, it should be noted that prior to enunciating the above statement of principle, Lord Denning in fact embarked on a fairly detailed survey of the existing law: in particular, the existing categories, all of which in fact involve some form of wrongdoing by the defendant. ${ }^{71}$ It is true, however, that Denning does state that there is no real need for proof of "any wrongdoing.", ${ }^{, 72}$ However, it is suggested that this is itself inconclusive because Denning is utilising the concept of "wrongdoing" in the sense of

\footnotetext{
${ }^{64}$ The literature is voluminous. However, for excellent expositions of the doctrine of fundamental breach in the context of exception clauses, see the following works by Professor Brian Coote: "The Rise and Fall of Fundamental Brcach" (1967) 40 Australian L.J. 336; "The Effect of Discharge by Breach on Exception Clauses" [1970] C.L.J. 221; "The Second Rise and Fall of Fundamental Breach" (1981) 55 Australian L.J. 788; and "Discharge for Breach and Exception Clauses Since Harbutt's 'Plasticine'" [1977] C.L.J. 31.

${ }^{65}$ See supra n. 40 .

${ }^{66}[1980]$ A.C. 827.

67 Ibid.

${ }^{68}$ See Lord Denning, "This is My Life" [1986] Denning L.J. 17 at p.25.

${ }^{69}$ See [1975] 1 Q.B. 326 at 339.

${ }^{70}$ See e.g., the House of Lords decision of National Westminster Bank plc v. Morgan [1985] A.C. 686 at 707-708 per Lord Scarman.

${ }^{71}$ These include duress of goods, unconscionable transactions, undue influence, undue pressure and salvage agreements: see generally [1975] 1 Q.B. 326 at 337-339. A notable omission is economic duress, but this is due to the fact that its modern beginnings can be traced to a couple of years after the decision in Lloyd's Bank Ltd. v. Bundy itself: see, in particular, Occidental Worldwide Investment Corp. v. Skibs A/S Avanti (The Siboen and the Sibotre) [1976] 1 Lloyd's Rep. 292 (noted, J.Beatson, "Duress by Threatened Breach of Contract" (1976) 92 L.Q.R. 496).

${ }^{72}$ See [1975] 1 Q.B. 326 at 339.
} 


\section{DENNING LAW JOURNAL}

the intention to bring distress to the other party, as opposed to a standard embodied in the law itself.

There is no reason in principle, in fact, why the courts should not adopt a broad approach analogous to that advocated by Lord Denning in Lloyd's Bank Ltd. v. Bundy. ${ }^{73}$ I have ventured to suggest elsewhere that the development of the doctrine of unconscionability may be a viable alternative instead. ${ }^{74}$

Another area where Lord Denning thought that justice ought to be done pertained to contracts to confer benefits on third parties. ${ }^{75}$ Indeed, in an extra-judicial context, he argues that the departure from the Christian Ethic in the nineteenth century in favour of a philosophy of giving untrammelled reign to the concept of freewill had now been discredited and that, therefore, "it is to be hoped that soon there will be restored the principle that person who makes a solemn promise must keep it" and hence, there should be recognised contracts for the benefit of third parties. ${ }^{76}$ Denning thus strenuously attempted to effect a change in the law in this particular context, but to no avail. ${ }^{77}$

Recent (and not so recent) events appear, however, to have vindicated Denning's views in this particular sphere of contract law. ${ }^{78}$

${ }^{73}$ [1975] 1 Q.B. 326.

${ }^{74}$ See e.g., A.Phang, "Undue Influence - Methodology, Sources, Linkages" [1995] J.B.L. 552 at pp.570-574 and, by the same author, "Economic Duress: Recent Difficulties and Possible Alternatives" [1997] R.L.R. 53 at pp.63-64, as well as "Tenders, Implied Terms and Fairness in the Law of Contract" (1998) 13 J.C.L.126 at pp.137-140. This would also meet the objection that there is no element of wrongdoing involved.

${ }^{75}$ And see Atiyah, supra n.38 at p.45: "Lord Denning has never had much love for the doctrine of privity."

${ }^{76}$ See Denning, "The Universities and Law Reform" supra n. 8 at pp.261-262. See also supra n.40.

${ }^{77}$ See, in particular, Lord Denning's dissenting judgment in Scruttons Ltd. v. Midland Silicones Ltd. [1962] A.C. 446 and his judgment in Beswick v. Beswick [1966] 1 Ch. 538 (an approach that was rejected by the House of Lords: see [1968] A.C. 58).

${ }^{78}$ See $e . g$., The Eurymedon [1975] A.C. 446 and The New York Star [1980] 3 All E.R. 257. There have been developments in the Australian and Canadian contexts as well: see e.g., the Australian High Court decision of Trident General Insurance Co. Ltd. v. McNiece Bros. Pty. Ltd. (1988) 165 C.L.R. 107 and the Canadian Supreme Court decision of London Drugs Ltd. v. Kuehne \& Nagel International Ltd. [1993] 1 W.W.R. 1.

In addition, and perhaps even more significantly, the U.K. Law Commission has recently published a Report containing proposals for legislative reform - the basic thrust of which is to allow third parties to avail themselves of the benefit of contracts under certain stipulated circumstances: see Privity of Contract: Contracts for the Benefit of Third Parties (H.M.S.O., Law Com. No.242, Cm.3329, July, 1996). See also A.Burrows, "Reforming privity of contract: Law Commission Report No. 242" [1996] L.M.C.L.Q. 467. In an even more recent development, the Contracts (Rights of Third Parties) Bill has just been introduced in Parliament. 
(iii) Other Areas:

It will be seen that the basic (substantive) pattern underlying Denning's judgments in the law of contract is replicated in other areas of the law.

Constraints of space preclude an even cursory discussion and the reader is directed to the various learned articles on specific topics in this volume. However, it might be very briefly mentioned that Denning's various seminal contributions ${ }^{79}$ have almost always been marked by his religious beliefs. For example, he viewed the law of negligence as embodying a moral element, ${ }^{80}$ and explicitly refers to Christianity in the context of Lord Atkin's seminal "neighbour principle" enunciated in Donoghue v. Stevenson. ${ }^{81}$ More generally, his views on sexual morality (though criticised $^{82}$ ) are entirely consistent with Christian morality.

However, Denning has been often trenchantly criticised for his approach towards (in particular) trade unions in the sphere of labour law. ${ }^{83}$ Even here, however, it could be argued (although this is not to state that he was invariably correct) that he was concerned to curb the abuse of power, thus preserving the rights of individual workers as well as the very structure of the nation itself. This is not, of course, to state that Denning was always right. However, the other extreme should also be avoided, viz., the argument to the effect that Denning was irretrievably (and, worse still, irrationally) biased against trade unions.

Indeed, it may be said that Denning also brought a realistic and practical view to bear on the entire issue of submission to the authority of the State in a balanced fashion, for he was of the view that the State ultimately "derives its authority from God." Equally well, Denning saw his general

\footnotetext{
${ }^{79}$ See e.g., Nelson v. Larholt [1948] 1 K.B. 339 at 342 (restitution) and Candler v. Crane, Christmas \& Co. [1951] 2 K.B. 164 (liability for negligent misstatement: Denning's dissenting judgment, as vindicated by the House of Lords in Hedley Byme \& Co. Ltd. v. Heller \& Partners Ltd. [1964] A.C. 465).

${ }^{80}$ See Denning, supra n. 2 at p. 280.

${ }^{81}$ [1932] A.C. 562 at 580 . He observes that "Lord Atkin took the Christian precept as underlying the basis of his decision": see Denning, supra n.20 at p.7.

${ }^{82}$ See e.g., R.Geary, "Lord Denning and Morality" in Robson \& Watchman, supra n.6, at pp.74-86. The oft-cited decision in this regard is Ward v. Braford Corporation (1972) 70 L.G.R. 27 esp. at 35, per Lord Denning M.R. To be fair to Denning, however, in the same case, Phillimore L.J. echoed the same sentiments: see (1972) 70 L.G.R. 27 at 38.

${ }^{83}$ See the excellent and fair-minded essay by P.Davies \& M.Freedland, "Labour Law" in Ch.8 of Jowell \& McAuslan, supra n.6.

${ }^{84}$ See Denning, "Influence," supra n.19 at p.117 (and citing Romans 13:1).
} 
emphasis on the importance of individual freedom as entirely consistent with his adoption of Christian principles. ${ }^{85}$

But how is the balance ${ }^{86}$ between individual freedom and societal order to be achieved? The answer has in fact been referred to above: through Christian principles. However, one may ask, why are Christian principles appropriate unless they embody objective truth? My answer is that they do, and this is a proposition that we shall be returning to below. ${ }^{87}$

\section{Lord Denning's Attitude Towards Other Religions}

What, then, about Denning's attitude towards other religions and religious groups? His basic philosophy is that there ought to be freedom of religion. ${ }^{88}$ Indeed, his openness towards other religions is displayed, for instance, in his exhortation that "Christians and Jews should come together in the search for truth." ${ }^{, 89}$ All this despite the clear difference between Jewish and Christian beliefs, which Denning frankly and matterof-factly acknowledges. ${ }^{90}$ Indeed, in Landmarks in the Law, Denning devotes a significant portion of his book to the Jews. ${ }^{91}$

Insofar as Christianity is concerned, Lord Denning is firmly of the view that:

"[w]e have reached the point ... that whilst the Christian beliefs still form the foundation of our way of life, as I trust they always will, they are not to be enforced by law ${ }^{92}$ but by teaching and example. ${ }^{, 93}$

\footnotetext{
${ }^{85}$ See Denning, The Changing Law, supra n.8 at p.3. See also Lord Edmund-Davies, supra n.7 at p.45.

${ }^{86}$ See Sir Alfred Denning, Freedom Under the Law (Stevens \& Sons Limited, 1949) especially at pp.4-6.

${ }^{87}$ See the Section below entitled "The Relevance of Christian Apologetics."

${ }^{88}$ And see generally Denning, supra n.86 at pp.35 and 45-48 and, by the same author, supra n.32 at pp.116-117 as well as Freedom of Religion (William Ainslie Memorial Lecture, delivered at St. Martin-in-the-Fields on 17th November, 1955; The Cranbourn Press, 1955).

${ }^{89}$ See Lord Denning, Landmarks in the Law (Butterworths, 1984) at p.328.

${ }^{90} \mathrm{lbid}$ at p.314.

${ }^{91}$ See ibid at pp.309-329.

${ }^{92}$ The leading case that holds that Christianity is not part of the law of England is the House of Lords' decision in Bowman v. Secular Society Limited [1917] A.C. 406.

${ }^{93}$ See Denning, supra n.86 at p.47 and, by the same author, supra n.32 at pp.117-118.

However, there were, in Denning's view, limits, particularly with respect to religious cults: see The Road to Justice supra n.32 at p.237.
} 


\section{ON CHRISTIAN INFLUENCES AND APOLOGETICS}

\section{Introduction}

Given the very secular cast of societies in general and philosophy in particular, it is by no means unreasonable for the reader to ask why Lord Denning's natural law approach premised on Christianity should be persuasive in the first instance. Although constraints of space preclude an extended discussion, I shall attempt to set out (albeit in the briefest of fashions) some reasons as to why Lord Denning's stance is not in the least untenable. These reasons were never, explicitly at least, utilised by Denning, although I am sure that he would not disapprove of them. A brief note first on influences, however, would not be amiss.

\section{The Influence of William Temple ${ }^{94}$}

Denning does consistently refer to the work of the late Archbishop of Canterbury, William Temple. ${ }^{95}$ Indeed, Denning once described Temple as "one of the greatest thinkers of the present century.",96

To take but one instance, Denning recounts how Temple, in an address at the Inns of Court, commenced his message by saying, "I cannot say that I know much about the law, having been far more interested in justice., 97 Denning endorsed this view by criticising positivism and argued that people obeyed the law because they felt a "moral obligation" to do so. ${ }^{98}$

There is insufficient space and time to deal with William Temple's philosophy. But it is important to at least state that his philosophy was

\footnotetext{
${ }^{94}$ See generally, F.A. Iremonger, William Temple, Archbishop of Canterbury-His Life and Letters (Oxford University Press, 1948); A.M.Suggate, William Temple and Christian Social Ethics Today (T. \& T. Clark, 1987); C.W.Lowry, William Temple - An Archbishop for All Seasons (University Press of America, Inc., 1982); and J.Kent, William Temple - Church, state and society in Britain, $1880-1950$ (Cambridge University Press, 1992). Reference may also be made to the introductory essay on Temple by Canon A.E.Baker in William Temple, Religious Experience and other Essays and Addresses (James Clarke \& Co. Lid., 1958) at pp.1-31 as well as to the "Introduction" by R.Preston to the re-issue (in 1976 by Shepheard-Walwyn) of Temple's Christianity and Social Order: see ibid. at pp.5-26.

${ }^{95}$ See $e . g$. . A.T.Denning, "The Traditions of the Bar" (1955) 72 S.A.L.J. 43 at p.43 and, by the same author, supra n.32 at pp.1 and 34.

${ }^{96}$ See Denning, "Influence" supra n.19 at p.107.

${ }^{97}$ See Denning, supra n. 32 at p.1.

${ }^{98}$ See generally ibid at pp.1-3. See also Lord Justice Denning, "English Law and the Moral Law" (1954) The Listener 332. But $c f$. the late Professor H.L.A.Hart who (paticularly in the "Postscript" to the second edition of his classic work, The Concept of Law (2nd ed., Clarendon Press, 1994)) adopted a descriptive (as opposed to a prescriptive) approach in support of his positivist thesis: but cf. (in turn) A.Phang, "The Concept of Law' Revisited" [1995] Tydskrif Vir Die Suid-Afrikaanse Reg 403.
} 
very consistent with Denning's: both were based on Christian principles and it is no wonder, therefore, that Denning constantly cited from Temple's work and philosophy. Indeed, I would add that Temple's work and philosophy is very close (as I recently discovered) to the principles that I briefly allude to in the very next Section: in particular, with respect to the pervasively real (yet seemingly intractable) problem of how one is to reconcile the universal with the particular. ${ }^{99}$ Another significant point Temple deals with (in my view at least) is the role of the Holy Spirit in the life of the individual. ${ }^{100}$

\section{The Relevance of Christian Apologetics}

In an age characterised by pluralism, Christianity is by no means an attractive option. Even the adoption of the classical natural law approach (perhaps best embodied within the work of Aquinas, ${ }^{101}$ and which comes (it is suggested) closest to what Lord Denning would probably endorse) would necessarily entail a systematic defence of the Christian faith (popularly encompassed within the - perhaps semantically misleading rubric of "Christian apologetics"), lest the embrace of Christianity and its underlying values be thought to be mere assertions without any rational basis whatsoever.

Constraints of space again preclude an even cursory discussion but it is suggested that, as preliminary arguments, one would have to consider arguments centring on the existence of God, ${ }^{102}$ the creation-evolution

\footnotetext{
${ }^{99}$ See e.g., W.Temple, Mens Creatix (Macmillan and Co. Ltd./St. Martin's Street, London, 1st ed., 1917; reprint, 1949) at pp.36, 318-320 and 364-366 and, by the same author, Christus Veritas (Macmillan \& Co. Ltd., 1924) at pp.ix and 243-244; Nature, Man and God (Macmillan and Co. Ltd./St. Martin's Street, London, 1st ed., 1934; reprint, 1953) at pp.184, 245, 296-297, 299-300, 306-307, 318 and 354-355; and Christian Faith and Life (Student Christian Movement Press, 1931) at pp.24, 53 and 110.

${ }^{100}$ See e.g., Temple, Mens Creatix, ibid at pp.342-343 and, by the same author, Christus Veritas, ibid at p.155 and Ch.XV; Nature, Man and God, ibid at p.446; and Christian Faith and Life, ibid at Ch. VI.

${ }^{101}$ See e.g., R.J.Henle, S.J., St. Thomas Aquinas - The Treatise on Law (University of Notre Dame Press, 1993) and E.Gilson, The Philosophy of St. Thomas Aquinas (translated by E.Bullough, 1929, and edited by G.A.Elrington - Dorset Press Reprint). Cf. A.J.Lisska, Aquinas's Theory of Natural Law - An Analytic Reconstruction (Clarendon Press, 1996). But $c f$. W.Temple, "Thomism and Modern Needs" in W.Temple, Religious Experience and Other Essays and Addresses (James Clarke \& Co. Ltd., 1958) at pp.229-236.

${ }^{102}$ These would include, inter alia, the cosmological argument as well as the argument from design. See generally e.g., J.P.Moreland, Scaling the Secular City - A Defense of Christianity (Baker Book House, 1987) and J.P.Moreland \& K.Nielsen, Does God Exist? The Debate between Theists \& Atheists (Prometheus Books, 1993). For a particularly accessible (yet nuanced) account (which comes down on the side of the existence of God), see R.Swinburne, Is There A God? (Oxford University Press, 1996).
} 


\section{NATURAL LAW FOUNDATIONS}

debate ${ }^{103}$ and (in a related vein) the issue of probabilities. ${ }^{104}$ It should also be mentioned that these various issues and arguments are themselves also linked across disciplines. ${ }^{105}$

More directly, one would have to consider the claims of Christianity itself. These would include the arguments of C.S. Lewis with respect to the claims of Jesus, ${ }^{106}$ arguments with regard to the authenticity of the Bible ${ }^{107}$ as well as the arguments demonstrating why Jesus was in fact resurrected from the dead. ${ }^{108}$ It should also be mentioned that Christianity enables the seemingly abstract and universal concept God to be objectively real, thus integrating the universal and the particular. This occurs in at least two related ways. First, as Jesus Christ claimed to have come from God the Father, to be the Son of God, indeed God Himself, but in the form of man (in order to die for sinners and to be thereafter resurrected from the dead and to ascend to heaven), we find that, if this claim be established, there is the confluence (indeed, unity) of both the infinite and particular in one Person. In addition, the universal and the particular meet inasmuch as the divinity of God (in Jesus Christ) is also testable both through logic as well as historical argument.

On a practical level, it is suggested that the Holy Spirit is also part of the Godhead of the Trinity and provides the individualised guidance to each person transcending space and time: truth is thus imparted in an individualised fashion and we are no longer left with the frustration that stems from the absence of linkage between the universal and the particular which gives rise (in turn) to an inability to test an abstract belief and a contrasting resignation to (and even feeling of despair in) individual

\footnotetext{
${ }^{103}$ See e.g., Phillip E.Johnson, Darwin on Trial (2nd ed., Intervarsity Press, 1993).

${ }^{104}$ See generally the works cited at supra n. 102.

${ }^{105}$ See e.g., Phillip E.Johnson, Reason in the Balance - The Case Against Naturalism in Science, Law \& Education (Intervarsity Press, 1995) and C.S.Lewis, Miracles (Fount/HarperCollins, 1947; reissue, 1974).

${ }^{106}$ See C.S.Lewis, Mere Christianity (Macmillan Publishing Company, rev.ed., 1952; 1 st paperback ed., 1960) at pp.55-56.

${ }^{107}$ See e.g., F.F.Bruce, The New Testament Documents: Are They Reliable? (Intervarsity Press, 5th rev. ed., 1960).

${ }^{108}$ See e.g., J.McDowell, Evidence That Demands A Verdict, Vols.I \& II (Here's Life
} Publishers, 1972 \& 1979); J.W.Montgomery, History and Christianity (reprint: Intervarsity Press, 1971); Sir N.Anderson, Jesus Christ: the witness of history (Intervarsity Press, 1985); S.Greenleaf, The Testimony of the Evangelists: The Gospels Examined by the Rules of Evidence Administered in Courts of Justice (reprint: Kregel Classics, 1995); Frank Morison, Who Moved the Stone? (Faber \& Faber, 1958); R.Clifford, Leading Lawyers' Case for the Resurrection (Canadian Institute for Law, Theology \& Public Policy, 1st Canadian ed., 1996); and N.L.Geisler, The Battle for the Resurrection (Thomas Nelson Publishers, 1989). It is of no mean significance that the vast majority of the authors cited in the present note are lawyers. 
relativity. Indeed, in Jesus Himself, as we have already seen, the universal and the particular are also united.

Much more remains to be unpacked, but I hope to have made out an at least prima facie case for consideration of the Christian natural law alternative. More importantly, I hope to have demonstrated that Denning's Christian natural law approach is by no means without any basis and that the charge of personal preference omits, amongst other things, to take into account the individualised guidance of the Holy Spirit that I am sure must have been an integral part of Denning's thought and work.

\section{CONCLUSION}

The traditional (or at least popular) view of Lord Denning is that of a maverick: of a judge who believes passionately in justice, but who so often gets around the law in order to achieve what he perceives to be justice in the case in hand. Put this way, the entire enterprise becomes a contradiction in terms: for the law should not be undermined if justice, the very object of the law itself, is to be achieved. But this argument presupposes that the law never goes wrong and, in the context of the common law and its methodology, this is a dangerous assumption to make: if nothing else, then because human beings are not infallible.

How, then, is the judge to know when (and when not to) depart from law that has somehow gone 'wrong'? 109 $^{10}$ This, in fact, entails the adoption of a natural law approach, which is to be contrasted with positivism which does not contemplate any necessary connection between law and morality. However, the options available to positivism, insofar as the legitimacy of the law is concerned, are not particularly attractive: mere circularity or infinite regress and it is, with respect, no answer to say that pragmatism demands that we have to arrive at a particular decision in any event. Any recourse to a pragmatic argument brings us dangerously close to (if not within the very depths of) personal preference. This is what led (in the main) to the demise of American Realism and is very much the cause of the woes facing Critical Legal Studies. Neither is liberalism's recourse to frameworks of ground rules, persuasive. ${ }^{110}$ This is simply the

${ }^{109}$ And see e.g., R.M.Dworkin, "Law, Philosophy and Interpretation" (1994) Archiv Fur Rechts-und Sozialphilosophie 463 esp.at pp.474-475 and, by the same author, "Objectivity and Truth: You'd Better Believe It" (1996) 25 Philosophy \& Public Affairs 87.

${ }^{110}$ The paradigm model, arguably at least, is to be found in the work of Professor John Rawls: see A Theory of Justice (Harvard University Press, 1971) and Political Liberalism (Columbia University Press, 1993). 
distinction between procedure and substance, and it is, with respect, woefully inadequate since the law is all of a piece. ${ }^{11}$

However, can the natural law argument be justified? Is it not subject to the same critiques canvassed in the preceding paragraph? It is submitted that it is not, provided it is premised on Christianity. Such a type of natural law is testable (both logically as well as historically) and has a functionality that lies, in the main, in the concept of the Trinity. The arguments are certainly at least as plausible as any on offer. And this is the approach that Lord Denning adopts. What appears like an arbitrary hunch is (in substance) a recourse not only to the value system underlying Christianity but also a receipt of supernatural guidance by the Holy Spirit. But this is not to state that such an approach guarantees even close to perfect results. If nothing else, it is also dependent on one very crucial element that God does not control, and chooses not to, our freewill: our decision to submit the problems and questions to Him for a co-operative solution and not wanting to take the law, as it were, into our own hands.

Lord Denning's greatest contribution, in my view, was not merely "the law" which he left behind but, rather, the spirit of justice that was guided by a supernatural force. Denning never wavered from the conviction that this was always so. More importantly, he persevered, right till his retirement: and has left a legacy of immeasurable proportions not only in the materials of the law itself but (more importantly) in the minds and hearts of not only those who are legally trained but also all those who are genuinely and passionately interested in justice. He brought a particularity and reality to the abstract concept of justice that tangibly demonstrated what it was all about.

In his reply to the various valedictory speeches made upon his retirement as Master of the Rolls, Denning ended thus:

"I wish I could say, as a great man did once, 'I fought a good fight; I finished the course; I have kept the faith.",112

He can, and ought to, say it.

111 And see, in the context of the law of contract, the incisive essay by Professor Atiyah, "Contract and Fair Exchange" (1985) 35 University of Toronto L.J. 1 (reprinted as Essay 11 in P.S.Atiyah, Essays on Contract (Clarendon Press, 1986)).

112 See "Valedictory Speeches upon the Impending Retirement of the Master of the Rolls" [1986] Denning L.J. 7 at p.15. The passage of Scripture he cites from is 2 Timothy 4:7. 